\title{
Constructing Identity and \\ Multicultural Art Education: \\ The Case of Taiwanese Festivals in Canada
}

Patricia Yuen-Wan Lin

Introduction

This research is a case study about why and how Taiwanese-Canadian immigrants construct their cultural identity through public festivals within a Canadian multicultural setting. This study aims to investigate both the content and the context of ethnic festivals and its implications for multicultural art education by using a Taiwanese-Canadian community as a case and ethnographic methods that involve interviewing community coordinators. In this paper, I discuss the following three aspects of this study:

- Leading questions

- Cultural theories and practice in multicultural art education

- Implications for multicultural art education

\section{Leading Questions}

\section{"It's not what you are that counts. It's what they think you are." ---Andy Warhol}

I stumbled on the inquiry of cultural identity due to my own perplexing need to make sense of my personal experiences whilst studying and residing in North America. I came to North America from Taiwan in the late 1980s. My first encounter of "who I am" happened at the American-Mexican border. The Mexican officer held my Taiwanese passport and informed me that it was an illegal document since it was not issued by a country (Taiwan is not recognized as a country by the United Nations). In other words, I didn't belong to a nation, and therefore did not have the legitimacy as a traveler to cross the border. Growing up in an authoritative society where I was educated to believe that the Taiwanese are the legitimate heir of Chinese political and cultural heritage (as opposed to the communist China), I was astonished at this gaze of other's denial of where I come from. This border incident uprooted my taken-for-granted educated Chinese pride, and plunged me into an identity crisis. Not only did I start questioning the public education in Taiwan, but also how the Taiwanese were perceived by others.

Identity arises from two aspects. Identity is not only about knowing internally who we are, but is also determined by external factors related to how others identify us. Like many of the Taiwanese middle class who chose to immigrant to North America, I felt disoriented at entering a multicultural society where everyone was expected to belong to a "place" and to "know" who you are. Why is it important to know who we are? How do we know who we are? What happens when one is mistakenly placed in an ethnic category by the mainstream society? 
"The simplification of culture"

---Bissoondath (1994) on the Canadian way of looking at the Chinese

During the first two years at the Ph.D. program, I chose to reside in the international graduate students' college at the University of British Columbia. Among the 80 residents, there were four Chinese students from the People's Republic, one from Hong Kong, one Malaysian-Chinese, two Chinese-Canadians who do not speak Chinese languages, and me from Taiwan. Whenever questions related to Chinese culture were raised during dinner conversations (a major activity of the college life), it seemed that the People's Republic represent an "authenticity" to the non-Chinese residents. Regardless of my interest and training in the subject, I have gradually come to accept that I come from what sinologists call, the "Chinese periphery." (Tu, 1994) Cultural superiority, where "the Center" dominates, is a common theme in cultural interactions, as found amongst the Parisian and Canadian-French Quebeco, or mainland Japanese and the Okinawa islanders. My frustration as a student well versed in the representation of Chinese culture, echoes the claim of the Hong Kong scholar Rey Chow (1993), that it is due to the gaze of the Western world that I am from a western capitalized island.

I also found that the Chinese are categorized as a single ethnicity by the Western world. The ignorance of the immigrant receiving society to the complexity of one ethnic diversity was astonishing when compared with the overwhelming reports on Asian-Pacific relations and the rhetoric multicultural education. Not only is the social diversity of Chinese groups ignored, but also the impact of Western influence through colonization in Asia. This major historical cause which results in the Chinese throughout the world having to live in different socio-economic and political structures (e.g. Communism in the People's Republic of China, British colonization in Hong Kong, Nationalism in Taiwan, and diasporic Chinese who grew up in Western countries, such as Chinese-Canadians) is regarded as trivial compared to the promising Pacific-Rim era proclaimed in the Vancouver media. Regardless of the extent of industrialization and westernization of the Chinese peoples, the Chinese are simply seen to be of the same ethnicity. Yet, I knew and personally experienced that I am different among the Chinese.

"Chineseness" in the 20th century is never a fixed category, and its meaning has to be interpreted within a given social context (Tu, 1994). Chinese culture is part of my cultural heritage, but not all. Besides Chinese influence, there is a major component of Japanese colonization and American effect on how I look at the culture in which I grew up and how I identify myself. The social interaction within this international university campus often irritated me since the acknowledged "difference" is both fixed and neutralized. How annoyingly simple it was to categorize the Chinese or the Eastern Indians who grew up under different social and historical backgrounds as a single entities? How does an ethnic group look at themselves through the "Western gaze" in North America? How does an ethnic group, for example, the Taiwanese, represent themselves through cultural activities under the rhetoric multiculturalism? Do the cultural activities offer a response to an official multicultural education policy or do they imply various subversive messages under the guise of multicultural education?

Marilyn Zurmuehlen's Working Papers In Art Education 1998-1999 


\section{"Let's go to Chinatown." \\ ---A local Vancouver understanding of Chinese culture}

Here in Vancouver, whenever we want to know about the Chinese, we go to Chinatown. Similarly, through the popularization of multicultural art education, there is a tendency for art educators who have Chinese children in their classrooms to get to know more about such students by including Chinese traditional arts in art curricula or to the available resources such as local Chinatown. But, do we see Chinese students living in Chinatown? Is Chinatown the creation of a Canadian site for cultural preservation, or is it the social reality where Chinese immigrants live?

This example indicates a significant gap between the Chinese traditional cultures in North America and the contemporary social context of our Chinese students. To explore this gap, I draw attention to the available resources for understanding the context of Chinese culture in Vancouver. Chinese immigration can be traced to the late 19th century. Under the then prevailing racist settlement policy towards Chinese labor workers, the early immigrants formed a specific North American Chinatown culture (Anderson, 1991). In contrast to the early Chinese labors, the increasing new arrivals since the 1970s were professional groups highly selected according to Canadian immigration policies. Gone were the days of immigrants who were associated with poverty and repressed social status (Adam-Moodley, 1992). While Chinatown is the symbolic representation of Chinese culture in Vancouver, the new immigrants from Hong Kong and Taiwan are congregating in suburban neighborhoods such as Richmond. This phenomenon occurs in other metropolitan cities in North America, such as Monterey Park in Los Angeles (Horton, 1994), and has typically been studied from a socio-economic perspective. Aside from the economic status of new immigrants, does Richmond imply a new way of cultural life which is far removed from the old familiar North American concept of Chinatown? To me, Chinatown is a "foreign" culture that needs to be interpreted and learned. It was an example of the Chinese diaspora which I did not learn in public schools in Asia, or associate with Taiwanese culture.

Building on the three examples above, I find a lower priority for the development of literature on the content of traditional non-Western visual arts in multicultural art education. While communicating with local art teachers, it has become apparent that it is more important to clarify the Western stereotypes of Chinese cultures by focusing on the internal operation cultural norms among Chinese immigrant communities. The differences between the cultural heritage which influences Chinese students while engaging in art, (making and appreciation) and the cultural tradition that art educators derived from reading instructional packages and visiting Chinatown, need to be examined. Not only there is a need to question the notion of tradition as defined by Canadian public schools, but also a need to present an argument to illustrate how modernization and immigration which define a particular Chinese cultural identity. Although ethnic cultures are included in multicultural art education, the aspect of modernization, cultural intervention, immigration experience, and how ethnic traditional cultural forms project the Western influence has been largely ignored 
by art educators. The importance of recognizing the social context of cultural productions is a responsibility of art educators. Rather than learning and teaching ethnic cultures as a historical heritage, I suggest that our concept of culture in art education needs to reflect the dynamics of cultural evolution in a contemporary multicultural society.

\section{Cultural Theories and Practice In Multicultural Art Education}

During the past three decades, an awareness of diverse cultures coexisting in society has captured the attention of scholars in the field of education, prompting numerous studies of "why" and "how" we recognize different cultures in a multiethnic society. The "why" aspect has been firmly established through socio-anthropological theories within multicultural education (e.g. Banks, 1989; Chalmers, 1981; McFee \& Degge, 1970; Wasson, Stuhr \& Petrovich-Mwaniki, 1990). The intent is to highlight similarities shared by cultural and ethnic groups and consequently to help students develop positive intergroup attitudes. Multicultural art education advocates cultural understanding through art. While the socio-anthropological aspects of art are manifested by cultural differences, theories of multicultural education emphasize the importance of equal distribution of power and resources among individuals in a culturally diverse society.

\section{Limits of Cultural Pluralism in Multicultural Art Education}

The anthropological theories of culture, mainly cultural relativism, has been the framework for art educators to justify the teaching of different cultures in North American multiethnic societies (e.g. McFee \& Degge, 1970; Chalmers, 1978, 1996; Freedman, Stuhr \& Weinberg, 1989). As a framework, however, the anthropological perspective has limitations for the study of cultures. The contemporary world is becoming interdependent, and the global economic interconnection between cultures has complicated the understanding of cultures. Cultural transmission in a homogeneous society is such an example. Cultural transmission which is generally studied through symbols or artifacts in anthropology, cannot engage in contemporary discourses since the transmission of culture could be influenced by external factors, such as encountering other cultures through trading or invasion. With the rise of mass media and technological development, cultural transmission as an isolated entity is severely questioned. Clifford (1988) maintains that culture is never static. Examples from contemporary circumstances indicate that the notion of culture can no longer remain as a tradition-bounded, historical, or timeless heritage because of the effects of immigration which creates cultural diversity, the modernization of Third World countries, and the increasing world art trading. Consequently, "authenticity" of a culture is modified by the frequent interaction between cultures. Concepts such as tradition and culture are undergoing conceptual shifts from a static to an active process (Hall, 1993; Rutherford, 1990).

Another limitation of the anthropological view of culture discussed in multicultural art education literature is the apolitical framework of anthropology which neglects the power relations between diverse ethnic groups. A function 
of culture involves the shaping of a collective identity. Williams' (1977) theory on cultural hegemony and Hall's (1994) analysis on collective identity through diaspora experiences amplify how culture provokes the politics of identity. The anthropological concept of culture in multicultural art education fails to address the issue of racism and power relations between cultures. Shanklin (1994) provides criticism of some anthropologists' refusal to address racism, after the wave of criticism of earlier anthropologists, who were largely seen as imperialistic. Influenced by the contemporary debate on the relationship between knowledge and power relations, several anthropologists support writing which contests the anthropological understanding of culture (Abu-Lughod, 1991; Appadurai, 1991; Clifford, 1988). The definition of cultural relativism and anthropology as a discipline is undergoing a period of reflection brought on by contemporary political and

social climates. With a notion of culture as a process being more "fluid", the issue of culture is not only the meaning and content as such, but how the meaning is manifested in a particular context. With the emergence of contemporary cultures which are interconnected and dynamic, cultural relativism as a cultural theory is shifting towards culture as an ideological vehicle (Turner, 1995).

Culture as a dynamic process and its relation to ethnic identity have become two important issues in the discussion of multicultural art education. Current academic debates on culture have prompted art educators to reflect upon cultural knowledge and power (Effland et al, 1996). Issues such as the role of cultural context, the relationship between content, context and community are among the few ideas that initiate the search for new meaning in multicultural art education (Hart, 1993; Neperud, 1995). Among multicultural art educators, Desai (1995) analyzes the ideologies underlying the current practice of multicultural art curricula in the United States. Desai argues that culture, defined from the anthropological understanding of ethnic cultures, presents art as a feature of a fixed set of cultural products and a biological/historical cultural heritage with no relevance of interconnectedness of contemporary society. Furthermore, ethnic cultures in multicultural art curricula lead to "partial representations" that are likely to perpetuate selected features of ethnic arts. The random selection of ethnic artistic styles and techniques are grouped in an almost supermarket type of display and arrangement.

Building on the work of cultural theorists, such as Gramsci, Raymond Williams, and Stuart Hall, Desai emphasizes a theory of culture as a process which is constantly in the process of transformation, redefinition, and negotiation. Since "art provides the context and material for the construction of individual subjectivity and collective identities" (p.5), ethnic cultural identity through art productions should not be viewed as a historical fact, but needs to be understood as a continuous process. She further stresses that cultural identity "has to be learnt and this learning does entail a rediscovery of hidden histories, traditions, and cultural expressions" (p. 144). Desai proposes a concept of culture as a hybrid entity to articulate the complexity of differences among various cultural groups. The hybridity of cultures assumes that cultures are constantly in the process of transformation. Acknowledging culture as a hybridity of such a process highlights the relational understanding of differences between specific 
historical moments and spaces (Garber, 1995). This notion of cultural hybridity allows for a macro perspective of understanding cultures without borders, and a micro perspective of social relations evident in our everyday life. Most importantly, discussing culture as being hybrid allows for the understanding of how people with different historical and cultural backgrounds interact within a multicultural setting (white included), and how specific representation encompasses meanings created by the people of differences.

\section{Multicultural Art Education Practice}

The weakness of current multicultural art education is exemplified in Hicks (1994) report on her teaching experience with African-American students. As a beginning teacher, Hicks assumes that African-American students' cultural heritage to be African art, yet finds her students' identities are situated within the American context rather than Africa. She argues that current multicultural education which defines culture through racial or historical continuity, or as a single coherent set of artifacts, is a "pedagogy of erasure", erasing the complexities of intra-cultural differences. It is also a "pedagogy of dislocation" that dislocates students' of immigrant families whose identities could be formed by diaspora experiences and assimilation within the host society. She finds that by linking African-American students with African culture not only erases the internal differences within cultures, but also dislocates the students' identity which are currently situated within an American context. Her study finds that multicultural art education which focuses only on content (e.g. traditional ethnic art models) and generalized ethnicity (e.g. African-Americans are assumed to affiliate with African cultural heritage) over-simplified the complexities of cultural formation. The identity of African-American students is deeply rooted in a specific time and cultural space which differs from their cultural origins and from that of the host societies. The current multicultural art education approach ignores the dynamics of cultural formation of various ethnic groups who are the participants of local education systems. Social elements due to the contact with the West, modernization, and immigrant experiences have been largely ignored by art educators who are often the mediators of cultural knowledge. Consequently, cultural knowledge introduced in the art classroom is criticized as a parade of selected ethnic arts, and as potentially producing ethnic stereotypes (Desai, 1995; Hicks, 1994; Neperud, 1995).

As a Chinese and Japanese art historian, I joined Hicks and Desai on questioning the inclusion of non-Western arts in North American art curricula. Multicultural art education has come a long way to implement cultural relativism and cultural pluralism in looking at the relationship between art and culture. Among the ideologies on why we teach multicultural art and the strategies on how to teach various art forms, I find there is a much needed critical analysis on power and culture. In other words, why Western European art has become the canon of world art and how non-Western cultures become hybridized in response to Western and local influences. I have argued that "Chinese culture" in the twentieth century is far from being static, and merely include traditional Chinese arts in an instruction package is to risk misunderstanding the contemporary cultural context of students coming from non-Western societies (Lin, 1997). 


\section{Implication for Multicultural Art Education}

There are two points that I want to suggest for the multicultural art educators community. First is the impact of cultural change within non-Western cultures; second is the importance of the local ethnic community. The first relates to the attitude of teachers to look at cultures which are intertwined with imperial history and modernization; the second refers to ethnic communities as strong resources for multicultural art educators.

\section{Cultural Changes Among Non-Western Cultures}

This research is being conducted between 1997-1998 in Vancouver, Canada. From my interviews with Taiwanese immigrants and participants at Taiwanese cultural festivals, I found that post-colonial cultural experiences and collective identity are critical when interpreting the cultural production of this immigrant community. In other words, cultural productions, such as ethnic festivals produced by such an ethnic community, reflects how the ethnic group sees themselves, and how they wish to be seen by the mainstream society. When looking at ethnic festivals, it is therefore important to address both the historical background of an ethnic community, and the relationship between a collective identity and the arts performed. In the case of Taiwanese-Canadian, the post-colonial Chinese diaspora experiences suggests how the TaiwaneseCanadian are organizing and constructing their cultural identity through the arts they select to present themselves.

Among various performing arts and art exhibitions of the Taiwanese Cultural Festival and Lunar New Year, the role of traditional arts plays a critical part in representing the Taiwanese community in Vancouver. Traditional arts, however, does not coincide with the Chinese arts which appear in Asian art instruction packages, nor with numerous references suggested in Asian art books. By participating in the process of decision-making for cultural festivals in the community, I took the position that tradition is constructed by the community members; part of the tradition is chosen to be remembered, just as some parts are purposely forgotten. My frame of reference echoes the reports in The Invention of Tradition, edited by cultural historians Hobsbawm and Ranger (1983). They present several case studies on how colonized cultures, such as India under Victorian Britain and Africa under European colonization, selected certain traditions as symbols of a collective identity. The authors argued that the notion of tradition, like the notion of culture, is constantly changing due to historical development and social changes. Identity, therefore, has a history. Traditional arts needs to be interpreted differently according to a particular time and space.

Multicultural art education tends to stress the similarities of ethnic cultures, and develops a popular theme or issue approach as a teaching strategy in the art classroom. As much as I appreciate the approaches, I think there are other perspectives to understand cultures. Examining the case of Taiwanese immigrants within a Chinese diasporic context in Canada, I firmly believe that many non-Western cultures are going through rapid cultural changes due to the process 
of decolonization and modernization. Imperialism has changed millions of people lives and cultural identities across the world. The experience of immigration also plays a major part in reconstructing peoples' cultural identities. While North American art educators tend to refer to non-Western cultures from the past, I would like to argue that teaching cultures, especially non-Western cultures which were shattered due to the contact with imperialism, has to be located within a specific time and space. In other words, I would highlight that cultural changes should be acknowledged among art educators who are interested in multicultural issues. In the Taiwanese immigrant case, cultural festivals could be "read" as a cultural text which is selected by the immigrants who are searching for a cultural identity within a Chinese diasporic context whilst simultaneously negotiating a cultural space within the Canadian multicultural society.

\section{Ethnic Communities as Multicultural Art Education Resources}

Ethnic community as a valuable resource for multicultural education through art has long been recognized by a number of art educators (e.g. Blandy \& Congdon, 1987; Chalmers, 1981; Chen, 1995; McFee \& Degge, 1970; Neperud, 1988; Petrovich-Mwaniki, 1997; Stuhr, 1995). For example, Wasson, Stuhr \& Petrovich-Mwaniki's (1990) Curriculum Guidelines for the Multicultural Classroom stands out as a strong proposal which emphasizes the ethnic community as a valuable resource for multicultural understanding. In their view, local communities are important resources through which teachers and students confront their own cultural identity and bias. Local communities also invite an ethnic pedagogy to reflect the socio-cultural and ethnic diversity in the classroom. Hicks (1994) proposes examining students' identities and the realities of other ethnic communities to avoid the pedagogy of erasure and dislocation of culture. Case studies based on ethnic community art learning, such as Chen (1995) on Chinese-American students learning experiences in the art classroom and Stuhr (1995) on curriculum guidelines based on the American Indian powwow festivals, are also important examples to find research issues and concerns to enrich multicultural art education literature.

In summary, there is little literature on the internal operational norms occurring in ethnic communities although ethnic community is identified as an important learning center for cross-cultural learning. How does the ethnic group define their cultural heritage? What are the conflicts, hierarchies, and differences of affirming cultural identity within a multicultural setting? Why are the artifacts made and for whom? How can the cultural activities practiced within the ethnic community be meaningful to multicultural education? Grounded in both Desai's cultural theorist framework and Hicks' emphasis on exploring the specificity of local communities, I propose to examine cultural formation and presentation within an ethnic community context to confirm and thereby extend the scope of multicultural art education. Within the discussion of cultural formation and presentation, I also suggest that one of the key elements in multicultural art education concerns the role of mediators between public institutions and ethnic communities. While the role of the teacher represents a public institution for educational change, the role of ethnic communities themselves should not be 
ignored as an important agent for the partnership between the school and the community.

\section{References}

Abu-Lughod, L. (1991). Writing against culture. In Fox R.G. (ed.). Recapturing anthropology: Working in the present.

Adam-Moodley, K. (Ed.). (1992). Beyond multicultural education: International perspectives. Calgary: Detselig.

Anderson, K. (1991). Vancouver's Chinatown: Racial discourse in Canada, 1875-1980. Montreal: McGill-Queen's University Press.

Appadurai, A. (1991). Global ethnoscapes, notes and queries for a transnational anthropology. In Fox, R.G. (Ed.). Recapturing anthropology: Working in the present. NM: School of American Research Press.

Banks, J. (1989). Integrating the curriculum with ethnic content: Approaches and guidelines. In Banks, J. and Banks, M. (Eds.). Multicultural education issues and perspectives. Boston: Allyn and Bacon.

Bissoondath, N. (1994). Selling illusions: The cult of multiculturalism in Canada. NY: Penguin Books.

Blandy, D. \& Congdon, K. (eds.). (1987). Art in a Democracy. New York: Teachers College Press.

Chalmers, F.G. (1978). Teaching and studying art history: Some anthropological and sociological considerations. Studies in Art Education, 20(1): 18-25.

Chalmers, F.G. (1981). Art education as ethnology. Studies in Art Education, 23(3): 6-14.

Chalmers, F.G. (1996). Celebrating pluralism: Art, education, and cultural diversity. Getty Center for Education in the Arts.

Chen, M. (1995). Art, culture, and Chinese-American experiences. Unpublished Ph.D. dissertation, Indiana University.

Chow, R. (1993). Writing diaspora: Tactics of intervention in contemporary cultural studies. Indiana University Press.

Clifford, J. (1988). The predicament of culture: Twentieth-century ethnography, literature, and art. Harvard University Press.

Desai, D. (1995). Multicultural storyboards: The politics of representation in multicultural art education. Unpublished Ph.D. dissertation, University of Wisconsin-Madison. 
Efland, A., Freedman, K. \& Stuhr, P. (1996). Postmodern art education: An approach to curriculum. Virginia: The National Art Education Association.

Freedman, K., Stuhr, P., \& Weinberg, S. (1989). The discourse of culture and art education. Journal of Multicultural and Cross-Cultural Research in Art Education, 7(1): 38-54.

Garber, E. (1995). Teaching art in the context of culture: A study in the borderlands. Studies in Art Education, 36(4): 218-232.

Hall, S. (1993). Culture, community, nation. Cultural Studies, 7(3): 349-63.

Hall, S. (1994). Cultural identity and diaspora. In Williams, P. and Chrisman, L. (Eds.), Colonial discourse and post-colonial theory: $A$ reader. (London: Harvester Wheatsheaf.

Hart, L. (1993). The role of cultural context in multicultural aesthetics. Journal of Multicultural and Cross-cultural Research in Art Education, 10/11: 5-19.

Hicks, L. (1994). Social reconstruction and community. Studies in Art Education, 35(3): 149-156.

Hobsbawm, E. and Ranger, T. (Eds.). (1983). The invention of tradition. Cambridge: Cambridge University Press.

Horton, J. (1994). The diversity of politics: Immigration in Monteray Park, California. California: UCLA Press.

Lin, P. (1997). Cultural identity and multicultural art education: A Chinese example. Canadian Review of Art Education, 24(2): 53-76.

McFee, J. \& Degge, E. (1970). Art, culture, and environment: A catalyst for teaching. Dubuque and Toronto: Kendall and Hunt.

Neperud, R. (1988). Conceptions of art in the service of art and aesthetic education: A critical view. Arts and Learning Research, 6(1): 95-106.

Neperud, R. (Ed.). (1995). Context, content, and community in art education: Beyond post-modernism. New York: Teachers College, Columbia University Press.

Petrovich-Mwaniki, L. (1997). Multicultural concerns in art education. Translations: From theory to practice. 7(1). Virginia: National Art Education Association. 
Rutherford, J. (Ed.), (1990). Identity: Community, culture, difference. London: Lawrence \& Wishart.

Shanklin, E. (1994). Anthropology and race. CA: Wadsworth Publishing Company.

Stuhr, P., Petrovich-Mwaniki, L., and Wasson, R. (1992). Curriculum guidelines for the multicultural art classroom. Art Education, 45(1): 16-24.

Stuhr, P. (1995). Social reconstructionist multicultural art curriculum design: Using the Powwow as an example. In R. Neperud (Ed.). Context, content, and community in art education: Beyond postmodernism. New York: Teachers College Press.

Tu, W. M. (1994). Cultural China: The periphery as the center. In Tu, W. M. (Ed.). The living tree: The changing meaning of being Chinese today. California: Stanford University Press.

Tu, W. M. (Ed.). (1994). The living tree: The changing meaning of being Chinese today. California: Stanford University Press.

Turner, T. (1995). Anthropology and multiculturalism: What is anthropology that multiculturalists should be mindful of it? In D. T. Goldberg (Ed.),

Multiculturalism: A critical reader. MA: Blackwell Publishers.

Wasson, R., Stuhr, P., and Petrovich-Mwaniki, L. (1990). Teaching art in the multicultural classroom: Six position statements. Studies in Art Education, 31(4): 234-246.

Williams, R. (1977). Marxism and literature. London: Oxford University Press. 